\title{
THE OPTIMISATION OF THE CORRELATION BETWEEN THE SUSPENSION AND STEERING SYSTEMS
}

\section{THIERHEIMER, W.W.; TANE, N. \& THIERHEIMER, D.C.}

Abstract: The problem of kinematical, dynamical and mathematical models is considered to characterize the dynamical behaviour of vehicles on curvilinear movement. In this particular case we considered the elements that have big influence in dynamic behavior of the automotive, such as: steering geometry, the particular aspects regarding constructive solution. The differential equation described in here was solved using the Laplace's method. The theoretical and experimental data comparison confirms with good accuracy the hypothesis made on the study of vehicle's stabilization system.

One can assert that the present study opens the path to new research topics concerning the suggested solution, such as other networks in controlling the course influence on the spring rigging and implicitly on vehicles' safety in traffic.

Key words: kinematics, control, suspension, steering, maniability, safety


Authors' data: Dr. Thierheimer, W[alter] W[ilhelm]*; Prof. Tane, N[icolae]**; Thierheimer, D[iana] C[amelia]*, *Transilvania University Brasov, Politehnicii str., nr. 3, ap. 6, 500019, Brasov, RO, **Transilvania University of Brasov, Jupiter Str., nr. 2, sc. E, ap. 62, 500360, Brasov, RO, thierheimer@unitbv.ro, boldor@vega.unitbv.ro, nictan54@unitbv.ro

This Publication has to be referred as: Thierheimer, W[alter] W[ilhelm]; Tane, $\mathrm{N}$ [icolae] \& Thierheimer, D[iana] C[amelia] (2008). The Optimisation of the Correlation Between the Suspension and Steering Systems, Chapter 72 in DAAAM International Scientific Book 2008, pp. 881-890, B. Katalinic (Ed.), Published by DAAAM International, ISBN 978-3-901509-66-7, ISSN 1726-9687, Vienna, Austria DOI: $10.2507 /$ daaam.scibook.2008.72 